\title{
TRANSCRANIAL DOPPLER SONOGRAPHY IN TWO PATIENTS WHO UNDERWENT DECOMPRESSIVE CRANIECTOMY FOR TRAUMATIC BRAIN SWELLING
}

\author{
Report of two cases
}

\author{
Edson Bor-Seng-Shu ${ }^{1}$, Manoel Jacobsen Teixeira ${ }^{1}$, Roberto Hirsch", \\ Almir Ferreira de Andrade', Raul Marino $\mathrm{Jr}^{3}$
}

\begin{abstract}
The role of decompressive craniectomy in the treatment of severe posttraumatic cerebral swelling remains quite a controversial issue. To the best of our knowledge, there is no study demonstrating the effect of decompressive craniectomy on cerebral blood flow (CBF) velocity by means of transcranial Doppler sonography (TCD). We present two patients who developed traumatic brain swelling and uncontrollable intracranial hypertension with coma and signs of transtentorial herniation. One patient underwent bifrontal, while the second, unilateral, frontotemporoparietal decompressive craniectomy with dural expansion. In both patients, TCD examinations were performed immediately before and after surgery to study the cerebral hemodynamic changes related to the operations. Pre and postoperative TCD examinations demonstrated a significant increase in blood flow velocity in the intracranial arteries in both subjects. In conclusion, our cases suggest that decompressive craniectomy with dural expansion may result in elevation of CBF velocity in patients with massive brain swelling. The increase in CBF velocity appears to occur not only in the decompressed hemisphere, but also on the opposite side.
\end{abstract}

KEY WORDS: brain swelling, cerebral hemodynamics, decompressive craniectomy, head injury, intracranial hypertension, transcranial Doppler sonography.

\begin{abstract}
Doppler transcraniano em doentes com tumefação encefálica pós-traumática submetidos à craniectomia descompressiva: relato de dois casos

RESUMO - Atualmente, as controvérsias sobre os benefícios da craniectomia descompressiva no tratamento de doentes com tumefação encefálica pós-traumática ainda existem. Não há estudos disponíveis na literatura médica sobre os efeitos da craniectomia descompressiva na hemodinâmica encefálica avaliados pelo Doppler transcraniano. Estudamos dois doentes com tumefação encefálica pós-traumática associada à hipertensão intracraniana e evidências de herniação transtentorial. Um deles foi submetido à craniectomia bifrontal e outro, à craniectomia frontoparietotemporal unilateral. O primeiro doente apresentou seqüela neurológica moderada e reintegração social, enquanto o segundo manteve-se em estado vegetativo. Exames de Doppler transcraniano realizados imediatamente antes e após a cirurgia revelaram aumento significativo da velocidade do fluxo sangüíneo nas artérias intracranianas de ambos os doentes. Concluiu-se que a craniectomia descompressiva com plástica de ampliação da dura-máter pode resultar em elevação da velocidade do fluxo sangüíneo encefálico nestes doentes. O aumento da velocidade do fluxo sangüíneo pode ocorrer nos hemisférios cerebrais do lado operado e, também, do lado oposto.
\end{abstract}

PALAVRAS-CHAVE: tumefação encefálica, hemodinâmica cerebral, craniectomia descompressiva, traumatismo craniencefálico, hipertensão intracraniana, doppler transcraniano.

To date, despite modern advances in understanding, monitoring, and treating increased intracranial pressure (ICP), patients suffering from uncontrollable intracranial hypertension due to trauma- tic brain swelling most often either die or survive in an extremely disabled state ${ }^{1-3}$. It is well known that intracranial hypertension can lead to a reduction in cerebral perfusion pressure (CPP) and a potential

'Staff Physician, Division of Neurosurgery, Hospital das Clínicas, São Paulo University Medical School, São Paulo SP, Brazil (FMUSP); ${ }^{2}$ Staff Physician, Division of Neurology, Hospital das Clínicas; ${ }^{3}$ Chairman, Division of Neurosurgery, Hospital das Clínicas FMUSP.

Received 14 July 2003, received in final form 25 February 2004. Accepted 30 March 2004.

Dr. Edson Bor-Seng-Shu - Rua Loefgreen 1272 - 04040-001 São Paulo SP - Brasil. E-mail: edsonshu@hotmail.com 


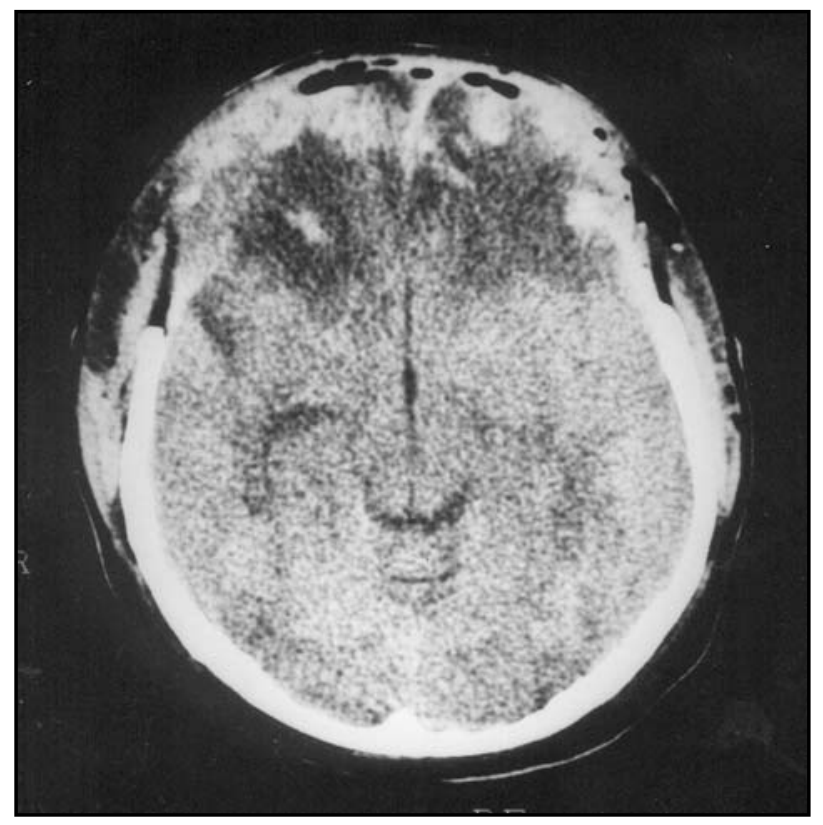

Fig 1. CT scan of patient 1 after bifrontal decompressive craniectomy.

decrease in cerebral blood flow (CBF). As a consequence, secondary ischemic insults and increases in cerebral swelling may occur ${ }^{4-10}$.

If conventional medical therapy fails in patients with refractory intracranial hypertension due to cerebral swelling, decompressive craniectomy with dural augmentation may be indicated as a last resort ${ }^{11}$. However, the actual benefit of this surgical procedure on patient outcome remains a controversial issue in neurosurgical literature. There is no conclusion as to how effective this surgical treatment is, despite a series of publications ${ }^{2,12-20}$. Moreover, there are few investigations in the literature concerning the hemodynamic benefits following a decompressive craniectomy ${ }^{21,22}$. To the best of our knowledge, there is no work demonstrating the effect of decompressive craniectomy on cerebral blood flow velocity by means of transcranial Doppler sonography (TCD) in head-injured patients.

In this study we present two patients with traumatic brain swelling and uncontrollable intracranial hypertension treated by decompressive craniectomy with dural opening. TCD, performed pre- and postoperatively, demonstrated a significant increase in blood flow velocity (BFV) in the intracranial arteries after surgical decompression. The significance of these findings from a cerebral hemodynamic point of view have been discussed.

\section{CASES}

Patient 1. A 28-year-old man was admitted to the hospital on October 25th, 1998, about 30 minutes after falling from a height (> 5 meters). On admission, his Glasgow coma scale (GCS) score was 12 while CT scan showed a diffuse traumatic subarachnoid hemorrhage, a brain swelling, and a small left-frontal contusion without significant mass effect. This patient underwent the placement of an ICP monitor and was transferred to neurological intensive care unit. Three days later, the patient deteriorated neurologically to a GCS score of 6 , and the ICP reached values between $35-40 \mathrm{mmHg}$, which was controlled by elevation of the head, mannitol solution and sedative drugs for a further 2 days, after which the ICP became uncontrollable, reaching $60 \mathrm{mmHg}$. At this time, a slight right hemiparesis was also noted. CT scan was
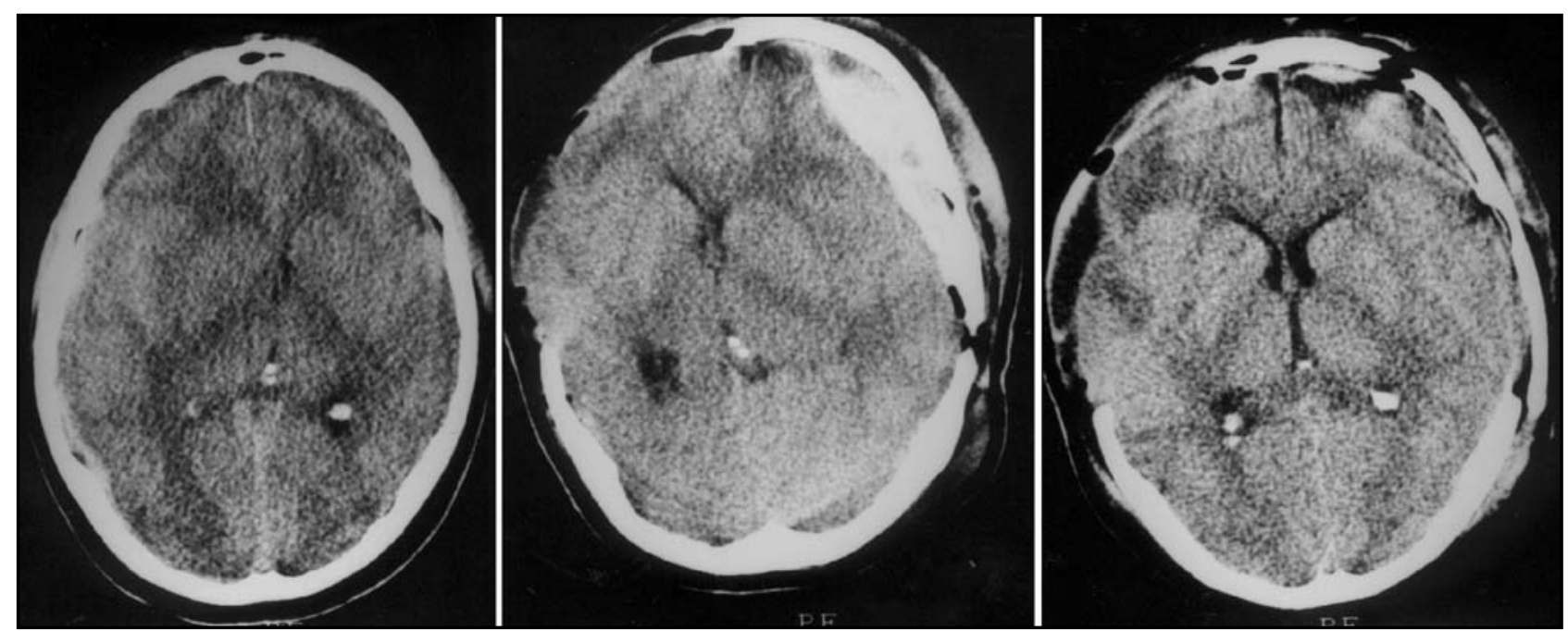

Fig 2. Serial noncontrast CT scans of patient 2. A, initial CT scan showing predominantly hemispheric swelling and midline shift. The patient was comatose and there were clinical signs of transtentorial herniation. $B$, the next day, the patient developed an uncal pupil on the left. CT scan demonstrated a large subdural hematoma of delayed onset. C, CT scan at a late stage. 


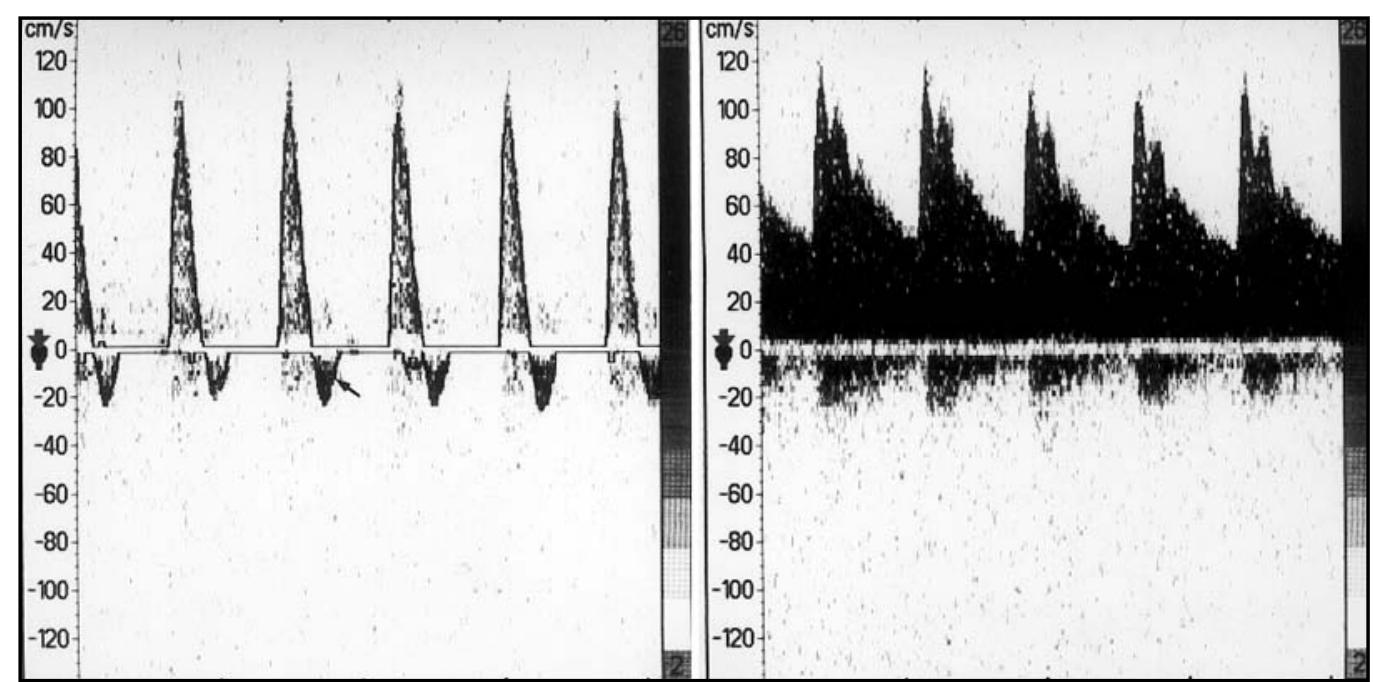

Fig 3. Transcranial Doppler spectral waveforms obtained from the right middle cerebral artery of patient 2. A, before decompressive craniectomy, the cerebral circulation was characterized by reduced blood flow velocity and high pulsatility index (PI) $(18 \mathrm{~cm} / \mathrm{s}$ and 7.09 , respectively). Note that during the diastolic phase, the blood flow velocity decreases continuously reaching zero value, and straight away, there is a reversion of flow direction (see arrow). This finding can indicate the presence of critical intracranial hypertension with a severe impairment of cerebral blood flow. $B$, immediately after surgery, the blood flow was restored to a unidirectional pattern, with more acceptable flow dynamics in terms of flow velocity and $P I$ (65 cm/s and 0.92, respectively).

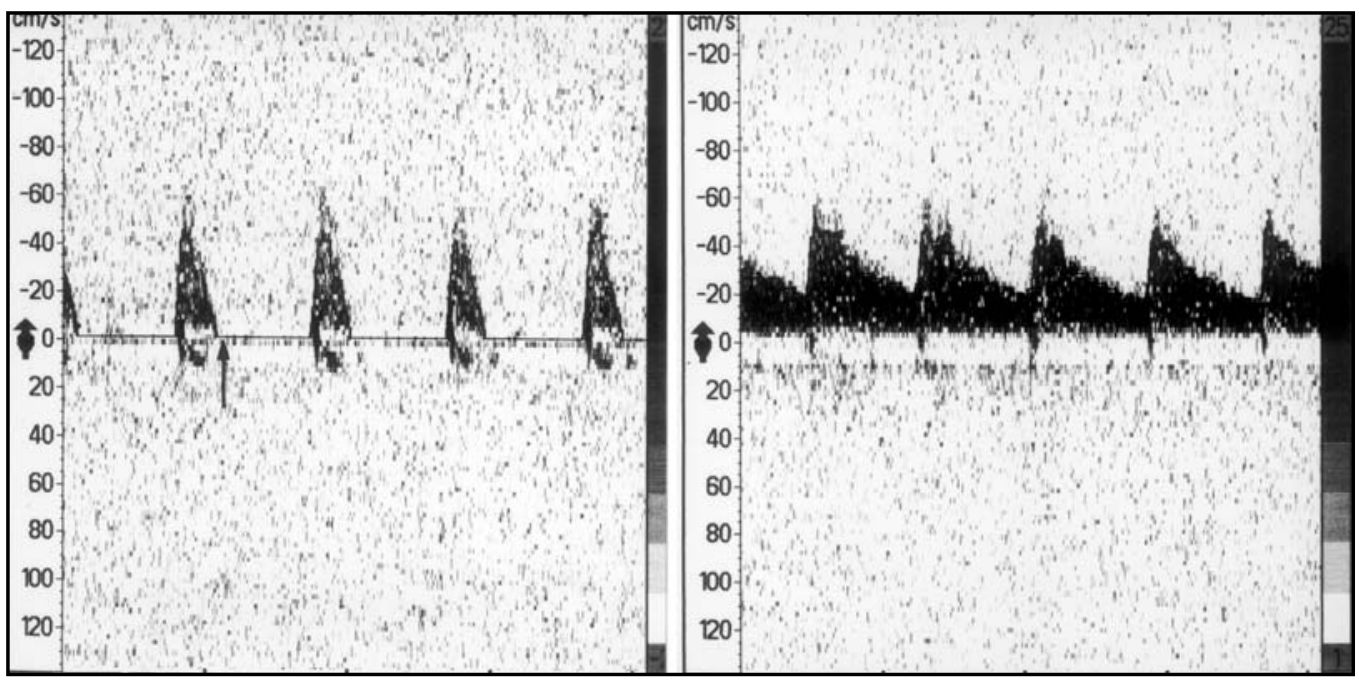

Fig 4. Transcranial Doppler velocity spectra of the basilar artery in the same patient (case 2). A, preoperatively, the critical high vascular resistance pattern resulted in a decrease of diastolic blood velocity until zero value. At this point, there was no cerebral perfusion (see arrow). $B$, postoperatively, the blood flow velocity, as well as the pulsatility index, was restored to acceptable levels $(31 \mathrm{~cm} / \mathrm{s}$ and 1.10 , respectively).

repeated and demonstrated worsening of the brain swelling. Both frontal and left temporal lobes were hypoatenuated. A large bifrontal decompressive craniectomy with dural expansion graft was indicated (Fig 1). TCD was performed immediately before and after surgery according to the technique proposed by Aaslid et al. ${ }^{23}$. The results are shown in Tables 1 and 2 . The physiological parameters such as mean arterial blood pressure, blood gases, and hematocrit were recorded during TCD stud- ies (Table 3). Subsequently, the patient recovered slowly. Four months after this trauma, the patient was awake, oriented, and walking with a mild hemiparesis. In the 2year-follow-up, the value of the Glasgow Outcome Scale score was 4 (moderate disability and social reintegration).

Patient 2. A 22-year-old man was admitted to the hospital on March 24th, 1999, with a 30 minutes history of falling from a bus in motion. The initial GCS score was 
Table 1. Changes in Cerebral Blood Flow Velocity before and after Decompressive Craniectomy. Blood Flow Velocity Values are expressed in $\mathrm{cm} / \mathrm{s}^{\mathrm{a}}$.

\begin{tabular}{|c|c|c|c|c|c|}
\hline Case & Side & Artery & $\begin{array}{c}\text { Preoperative } \\
\text { TCD }\end{array}$ & Postoperative & $\begin{array}{c}\text { Change } \% \\
\text { TCD }\end{array}$ \\
\hline \multirow[t]{9}{*}{1} & Right & MCA & 42 & 125 & 198 \\
\hline & & ACA & 44 & 131 & 198 \\
\hline & & Siphon & 40 & 116 & 190 \\
\hline & & Cervical ICA & 18 & 32 & 78 \\
\hline & Left & MCA & 44 & 149 & 239 \\
\hline & & ACA & 35 & 116 & 231 \\
\hline & & Siphon & 35 & 116 & 231 \\
\hline & & Cervical ICA & 16 & 26 & 62 \\
\hline & Basilar & & 29 & 53 & 83 \\
\hline \multirow[t]{9}{*}{2} & Decompressed & MCA & 18 & 65 & 254 \\
\hline & Side & ACA & 23 & 25 & 9 \\
\hline & & Siphon & 12 & 35 & 192 \\
\hline & & Cervical ICA & 16 & 33 & 106 \\
\hline & Opposite & MCA & 16 & 40 & 150 \\
\hline & Side & ACA & 35 & 42 & 20 \\
\hline & & Siphon & 23 & 40 & 74 \\
\hline & & Cervical ICA & 16 & 31 & 94 \\
\hline & Basilar & & 18 & 31 & 72 \\
\hline
\end{tabular}

aTCD, transcranial Doppler sonography; MCA, middle cerebral artery; ACA, anterior cerebral artery; ICA, internal carotid artery.

\begin{tabular}{|c|c|c|c|c|}
\hline Case & Side & Artery & $\begin{array}{c}\text { Preoperative } \\
\text { TCD }\end{array}$ & $\begin{array}{c}\text { Postoperative } \\
\text { TCD }\end{array}$ \\
\hline \multirow[t]{9}{*}{1} & Right & MCA & 1.38 & 1.15 \\
\hline & & ACA & 1.11 & 1.00 \\
\hline & & Siphon & 1.19 & 1.15 \\
\hline & & Cervical ICA & 1.16 & 0.97 \\
\hline & Left & MCA & 1.42 & 1.16 \\
\hline & & ACA & 1.21 & 0.88 \\
\hline & & Siphon & 1.42 & 1.19 \\
\hline & & Cervical ICA & 1.16 & 1.32 \\
\hline & Basilar & & 1.21 & 1.34 \\
\hline \multirow[t]{9}{*}{2} & Decompressed & MCA & 7.09 & 0.92 \\
\hline & Side & ACA & 3.90 & 0.83 \\
\hline & & Siphon & 5.27 & 1.33 \\
\hline & & Cervical ICA & 3.18 & 1.09 \\
\hline & Opposite & MCA & 5.87 & 1.30 \\
\hline & Side & ACA & 1.35 & 0.89 \\
\hline & & Siphon & 3.20 & 1.38 \\
\hline & & Cervical ICA & 3.29 & 1.05 \\
\hline & Basilar & & 3.00 & 1.10 \\
\hline
\end{tabular}

${ }^{\mathrm{T}} \mathrm{TCD}$, transcranial Doppler sonography; MCA, middle cerebral artery; ACA, anterior cerebral artery; ICA, internal carotid artery.

8, but this patient rapidly deteriorated to a GCS score of 6 and developed anisocoria with a greater right pupil. CT scan revealed a thin subdural hematoma on the right side (greatest thickness: $0.4 \mathrm{~mm}$ ) and brain swelling, main- ly in the right hemisphere. The midline shift from the right to the left was of $14 \mathrm{~mm}$ at the anterior septum, and the mesencephalic cisterns were compressed, as well as the right lateral ventricle (Fig 2A). TCD performed soon 
Table 3. Physiological Parameters During the Pre- and Postoperative Transcranial Doppler Sonography (TCD) Examinations ${ }^{\text {a }}$.

\begin{tabular}{llcc}
\hline Case & Parameters & Preoperative TCD & Postoperative TCD \\
\hline \multirow{3}{*}{1} & PaCO2 $(\mathrm{mmHg})$ & 37 & 40 \\
& Hematocrit $(\%)$ & 49 & 43 \\
& Mean ABP $(\mathrm{mmHg})$ & 108 & 93 \\
2 & PaCO2 $(\mathrm{mmHg})$ & 42 & 35 \\
& Hematocrit (\%) & 40 & 43 \\
& Mean ABP $(\mathrm{mmHg})$ & 90 & 84 \\
\hline
\end{tabular}

${ }^{a} \mathrm{TCD}$, transcranial Doppler sonography; $\mathrm{PaCO} 2$, arterial blood $\mathrm{CO} 2$ partial pressure; $\mathrm{ABP}$, arterial blood pressure.

after CT disclosed a significantly decreased BFV and an important increase in the pulsatility index (PI) (Tables 1,2). There was an oscillating flow pattern characterized by a discrete reversed-flow direction during the diastolic phase in the middle and anterior cerebral arteries (Fig $3 \mathrm{~A})$. In the basilar artery, the end diastolic BFV reached zero value (Fig 4A). This patient underwent a large right frontotemporoparietal decompressive craniectomy with dural augmentation. Postoperatively, TCD demonstrated an important increase in BFV along with a decrease in $\mathrm{PI}$, in relation to the preoperative values (Tables 1, 2). There was no longer an oscillating flow pattern in the intracranial arteries (Fig 3B) and the diastolic blood flow velocity was no longer zero (Fig 4B). The physiological parameters such as mean arterial blood pressure, blood gases, and hematocrit were recorded at the moment of each TCD study (Table 3). Approximately 24 hours later, this patient developed anisocoria with a greater left pupil and an increase in tension at the craniectomy site. CT scan disclosed a large left fronto-temporo-parietal subdural hematoma of delayed development (Fig 2B). This patient was brought to the operating room and the hematoma was evacuated by craniotomy (Fig 2C). On discharge from hospital, 5 months on, this patient remained in a vegetative state. In a two-year follow-up, the patient had not improved neurologically.

\section{DISCUSSION}

Transcranial Doppler sonography was first introduced by Aaslid et al..$^{23}$ in 1982, and quickly allowed new perspectives for assessing cerebrovascular hemodynamics. TCD has been validated scientifically and its use has become routine practice in recent years, in the diagnostic study of patients with severe head injury and cerebrovascular disease ${ }^{24}$. TCD allows a rapid, noninvasive, reproducible, and dynamic examination of intracranial circulation. The hemodynamic parameter, measured in real-time in the major intracranial arteries, is blood flow velocity. The direction of the blood flow is also record$\mathrm{ed}^{5,24,25}$. Since the reliability of findings is operator dependent $5,24,25$, for this study, all examinations were performed by an experienced TCD operator (senior author) so that the depth and angle of vessel insonation could be maintained as similar as possible, pre and postoperatively. TCD monitoring cannot give quantitative blood flow data, such as flow rate (in $\mathrm{ml} / \mathrm{min}$ ) or tissue perfusion (in $\mathrm{ml}$ $/ 100 \mathrm{~g} / \mathrm{min})^{25}$. However, it is possible to use TCD to follow relative changes in flow in a specific artery, over a period. Considering the principle that given the diameter of the evaluated arterial segment remains constant, any change in flow velocity correlates well with a change in cerebral blood flow in the territory of that vessel $\left.\right|^{5,25,26}$. This principle enables TCD to be used to evaluate the effect of various therapies, such as decompressive craniectomy, on relative changes in cerebral blood flow. Both of our patients presented a significant increase in CBF velocity after surgical decompression.

Currently, it is well known that the increase in ICP provokes changes in cerebral circulation, which may be evaluated with TCD hemodynamic parameters $5,6,9,24,25,27,28$. Researchers in TCD are now trying to estimate the cerebral perfusion pressure ${ }^{8}$ and predict the intracranial pressure curves ${ }^{29}$ in a noninvasive manner. An elevation in ICP causes an increase in cerebrovascular resistance (CVR), probably as a result of cerebral microcirculatory or venous compression. This elevation in CVR results in an increase in the pulsatility index (PI), which is defined by the formula (systolic velocity - diastolic velocity)/mean velocity. In patients with intact cerebral autoregulation, increases in ICP will cause an increase in the $\mathrm{PI}$ and no change in the mean flow velocity, if the CPP remains in the autoregulatory range. Further increases in ICP that bring the CPP below the range of autoregulation, will cause a further increase in $\mathrm{PI}$, as well as a decrease in mean flow velocity. When ICP reaches the level of the diastolic systemic blood 
pressure, the diastolic flow in the intracranial arteries ceases. At this point, high systolic peaks are still detectable and the blood stops during the diastolic phase of circulation. With a further increase in ICP, a to-and-fro, also called oscillating flow, pattern may appear, when the flow progress in the systole and, during diastole, a critically high ICP, CVR and a distended intracranial arteries eject the blood in a retrograde direction. When net forward flow is seriously reduced, severe ischemic brain damage or brain death may occur. With a persistent level of critically raised ICP, the intracranial waveform degrades to become a small systolic spike and then disappears altogether ${ }^{5,6,9}$. Case 2 presented a cessation of diastolic flow in the basilar artery (Fig 4A) and an oscillating progressive flow in the middle cerebral arteries (Fig 3A), translating to a critical compromise of intracranial circulation resulting from severe intracranial hypertension. Comparing the $\mathrm{PI}$ in both of our patients before and after decompression, it is evident that, preoperatively, the value of the PI was higher, indicating raised ICP. After surgical decompression, there was a significant decrease in PI (Table 2). The CBF of case 2 was restored to a unidirectional pattern and an acceptable value for diastolic velocity (Figs 3B and 4B). These cerebral hemodynamic findings could only be explained by a reduction of ICP due to decompressive craniectomy.

The diagnosis of posttraumatic vasospasm is important since it is a potential contributor to secondary ischemic injury, besides being a factor for worsening brain swelling ${ }^{30,31}$. Various studies have been published showing that vasospasm may occur in between 18.6 to $68 \%$ of severe head-injured patients during the posttraumatic course ${ }^{30,31}$. Once diagnosed, rational therapy strategies to increase CBF may be planned and instituted. The TCD criteria for diagnosing cerebral vasospasm have been improved over the years. The criteria adopted by Martin et al. ${ }^{31}$, which require both a threshold middle cerebral artery velocity of $120 \mathrm{~cm} / \mathrm{s}$ and a "Lindegaard" hemispheric ratio (mean MCA blood velocity divided by the ipsilateral extracranial internal carotid artery blood velocity) greater than 3 , permit differentiation between elevated velocities secondary to increased CBF, and those which are elevated chiefly as a result of arterial narrowing ${ }^{31,32}$. For the diagnosis of vasospasm in the anterior cerebral arteries, a velocity of $130 \mathrm{~cm} / \mathrm{s}$ or $140 \mathrm{~cm} / \mathrm{s}$ is required so that the specificity of the TCD would be $96 \%$ to $100 \%{ }^{33}$. Taking all this into account on when analyzing postoperative TCD data, case 1 pre- sented TCD hemodynamic results indicative of vasospasm in both ACA and left MCA. This patient (case 1) presented subarachnoid hemorrhage on CT scan and developed hemiparesis during the posttraumatic course. This fact could increase the positive predictive value of these TCD findings. We believe that before surgical decompression, case 1 had already presented vasospasm, which could not be demonstrated by TCD due to concomitant raised ICP, since the sensitivity of TCD in the diagnosis of vasospasm is reduced in the presence of elevated ICP ${ }^{34}$. In theory, this is a dangerous cerebral hemodynamic condition, in which the vasospasm in the large arteries ( $M 1$ and $A 1$ ) leads to increased macrovasculature resistance while at the same time, intracranial hypertension increases the microvasculature resistance such that the effect on $\mathrm{CBF}$ reduction is more significant. In case 1 , probably the association of vasospasm and intracranial hypertension resulted in $\mathrm{CBF}$ reduction to an ischemic threshold level where the vicious circle of low CBF, with ischemia, cerebral swelling and intracranial hypertension could be established and maintained. We believe that the indication of decompressive craniectomy in this patient played an important role in breaking this vicious circle, providing the possibility of reducing ICP and increasing CBF velocity.

Rinaldi et al. ${ }^{21}$ studied the hemodynamic effects of decompressive craniectomy and dura-mater opening in rabbits with brain edema due to cold-induced lesions and demonstrated that in craniectomized animals, decompression was immediately followed by a significant decrease in ICP to basal levels and a simultaneous increase in the internal cervical blood flow velocity to normal values, thus indicating a decrease in cerebrovascular resistance. Following this, Yamakami and Yamaura ${ }^{22}$ used singlephoton emission computerized tomography (SPECT) with $99 \mathrm{~m}$ technetium-hexamethyl-propyleneamine oxime in five patients who underwent large unilateral decompressive craniectomies for posttraumatic hemispheric brain swelling. They observed that a focal CBF increase (hyperperfusion area) occurred in the decompressed brain within 24 hours after surgery. The first study disclosed indirect evidence of intracranial hemodynamic improvement in rabbits, since it demonstrated an elevation of cervical internal carotid artery blood flow velocity after surgical decompression, whereas our work demonstrated an increase in blood flow velocity, directly in human intracranial arteries. The latter work demonstrated hyperperfusion in decompressed brain areas 
using SPECT, which may support our data in terms
of the CBF increase after this operation.

In conclusion, our cases suggest that decompressive craniectomy with dural expansion may result in an elevation of CBF velocity in patients with massive cerebral swelling. The increase in CBF velocity appears to occur not only in the decompressed hemisphere, but also on the opposite side. Prospective studies concerning this issue are warranted.

\section{REFERENCES}

1. Marshall LF, Gautille T, Klauber MR. The outcome of severe closed head injury. J Neurosurg 1991;75:28-36.

2. Polin RS, Shaffrey ME, Bogaev CA, et al. Decompressive bifrontal craniectomy in the treatment of severe refractory posttraumatic cerebral edema. Neurosurgery 1997;41:84-94.

3. Marmarou A, Fatouros PP, Barzó P, et al. Contribution of edema and cerebral blood volume to traumatic brain swelling in head-injured patients. J Neurosurg 2000;93:183-193.

4. Muizelaar JP, Becker DP, Lutz HA, Newlon PG. Cerebral ischemia after severe head injury: its role in determining clinical status and its possible treatment. In Villani R, (ed). Advances in neurotraumatology. Amsterdam: Excerpta Medica, 1984:92-98.

5. Newell DW. Transcranial Doppler ultrasonography. Neurosurg Clin N Am 1994;5:619-631.

6. Hassler W, Steinmetz H, Gawlowski J. Transcranial Doppler ultrasonography in raised intracranial pressure and in intracranial circulatory arrest. J Neurosurg 1988;68:745-751.

7. Morgalla MH, Krasznai L, Buchholz R, et al. Repeated decompressive craniectomy after head injury in children: two successful cases as a result of improved neuromonitoring. Surg Neurol 1995;43:583-590.

8. Czosnyka M, Matta BF, Smielewski P, Kirkpatrick PJ, Pickard JD. Cerebral perfusion pressure in head-injured patients: a noninvasive assessment using transcranial Doppler ultrasonography. J Neurosurg 1998; 88:802-808

9. Ducrocq X, Hassler W, Moritake K, et al. Consensus opinion on diagnosis of cerebral circulatory arrest using Doppler-sonography. Task Force Group on cerebral death of the Neurosonology Research Group of the World Federation of Neurology. J Neurol Sci 1998;159:145-150.

10. Yoo DS, Kim DS, Cho KS, Huh PW, Park CK, Kang JK. Ventricular pressure monitoring during bilateral decompression with dural expansion. J Neurosurg 1999;91:953-959.

11. Bullock R, Chesnut RM, Clifton G, et al. Guidelines for the management of severe head injury: Brain Trauma Foundation. J Neurotrauma 1996;13:639-734.

12. Kunze E, Meixensberger J, Janka M, Sörensen N, Roosen K: Decompressive craniectomy in patients with uncontrollable intracranial hypertension. Acta Neurochir (Wien) 1998;(Suppl)71:S16-S18

13. Kleist-Welch Guerra W, Gaab MR, Dietz H, Mueller JU, Piek J, Fritsch MJ. Surgical decompression for traumatic brain swelling: indications and results. J Neurosurg 1999;90:187-196.

14. De Luca GP, Volpin L, Fornezza U, et al. The role of decompressive craniectomy in the treatment of uncontrollable post-traumatic intracranial hypertension. Acta Neurochir 2000;(Suppl)76:S401-S404.
15. Meier U, Zeilinger FS, Henzka O. The use of decompressive craniectomy for the management of severe head injuries. Acta Neurochir Suppl 2000;(Suppl)76:S475-S478.

16. Münch E, Horn P, Schürer L, Piepgras A, Paul T, Schmiedek P. Management of severe traumatic brain injury by decompressive craniectomy. Neurosurgery 2000;47:315-323.

17. Taylor A, Butt W, Rosenfeld J, et al. A randomized trial of very early decompressive craniectomy in children with traumatic brain injury and sustained intracranial hypertension. Childs Nerv Syst 2001;17:154-162.

18. Whitfield PC, Kirkpatrick PJ, Czosnyka M, Pickard JH. Management of severe traumatic brain injury by decompressive craniectomy. Neurosurgery 2001;49:225-226.

19. Coplin WM, Cullen NK, Policherla PN, et al. Safety and feasibility of craniectomy with duraplasty as the initial surgical intervention for severe traumatic brain injury. J Trauma 2001;50:1050-1059.

20. Csókay A, Együd L, Nagy L, Pataki G. Vascular tunnel creation to improve the efficacy of decompressive craniotomy in posttraumatic cerebral edema and ischemic stroke. Surg Neurol 2002;57:126-129.

21. Rinaldi A, Mangiola A, Anile C, Maira G, Amante P, Ferraresi A. Hemodynamic effects of decompressive craniectomy in cold induced brain oedema. Acta Neurochir Suppl (Wien) 1990;(Suppl)51:S394-S396.

22. Yamakami I, Yamaura A. Effects of decompressive craniectomy on regional cerebral blood flow in severe head trauma patients. Neurol Med Chir (Tokyo) 1993;33:616-620.

23. Aaslid R, Markwalder TM, Nornes H. Noninvasive transcranial Doppler ultrasound recordings of flow velocity in basal cerebral arteries. J Neurosurg 1982;57:769-774.

24. Babikian VL, Feldmann E, Wechsler LR, et al. Transcranial Doppler ultrasonography: year 2000 update. J Neuroimaging 2000;10:101-115.

25. Martin NA, Doberstein C. Cerebral blood flow measurement in neurosurgical intensive care. Neurosurg Clin N Am 1994;5:607-618.

26. Kirkham FJ, Padayachee TS, Parsons S. Transcranial measurement of blood velocities in the basal cerebral arteries using pulsed Doppler ultrasound: velocity as an index of flow. Ultrasound Med Biol 1986;12:15-21.

27. Chan KH, Miller D, Mark Dearden N, Andrews PJD, Midgley S. The effect of changes in cerebral perfusion pressure upon middle cerebral artery blood flow velocity and jugular bulb venous oxygen saturation after severe brain injury. J Neurosurg 1992;77:55-61.

28. Homburg AM, Jakobsen M, Enevoldsen E. Transcranial Doppler recordings in raised intracranial pressure. Acta Neurol Scand 1993;87:488-493.

29. Schmidt B, Klingelhöfer J, Schwarze JJ, Sander D, Wittich I. Noninvasive prediction of intracranial pressure curves using transcranial Doppler ultrasonography and blood pressure curves. Stroke 1997;28:2465-2472.

30. Lee JH, Martin NA, Alsina G, et al. Hemodynamically significant cerebral vasospasm and outcome after head injury: a prospective study. J Neurosurg 1997;87:221-223.

31. Martin NA, Patwardhan RV, Alexander MJ, et al. Characterization of cerebral hemodynamic phases following severe head trauma: hypoperfusion, hyperemia and vasospasm. J Neurosurg 1997;87:9-19.

32. Lindegaard KF, Nornes H, Bakke SJ, Sorteberg W, Nakstad P. Cerebra vasospasm diagnosis by means of angiography and blood flow velocity measurements. Acta Neurochir 1989;100:12-24.

33. Sloan MA. Transcranial Doppler monitoring of vasospasm after subarachnoid hemorrhage. In Tegeler CH, Babikian VL, Gomez CR, (eds). Neurosonology. St. Louis: Mosby, 1996:156-171.

34. Klingelhöfer J, Sander D, Holzgraefe M, Bischoff C, Conrad B. Cerebral vasospasm evaluated by transcranial Doppler ultrasonography at different intracranial pressures. J Neurosurg 1991;75:752-758. 